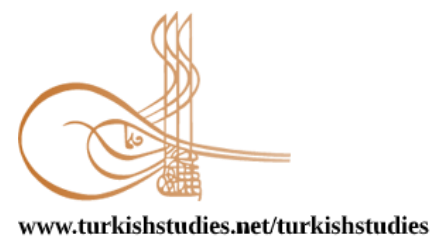

Turkish Studies

\title{
Pandemi Tarihinde Üç Hastalık ve Covid-19 Pandemisinin Sosyal Etkisinin Bu Hastalıklarla Değerlendirilmesi
}

\author{
Three Diseases in the History of Pandemic and Evaluation of the Social Effect of Covid-19 \\ Pandemic with These Diseases
}

\author{
Çağatay Üstün*
}

\begin{abstract}
When it is examined in terms of history of medicine, it is known that there are big pandemics in the world and their medical, social, ethical and moral results as well. Since the concept of the disease factor has not been known in the past centuries, it is seen that the affected communities have remained in fear, anxiety and panic, and different changes have been experienced. However, it is noticed that the diseases are not as effective as they were in the past due to the increase in medical diagnosis and opportunities in the treatment experienced in the last 100 years. Despite this, it is undeniable fact that viral diseases such as HIV and AIDS in the 20th century, and SARS, MERS, Ebola in the 21st century caused great health problems. Finally, the viral epidemic disease(described as COVID-19), which started in December 2019 in the city of Wuhan in Hubei province of China, rapidly spread around the world and turned into a pandemic and resulted in changing the course of the history of pandemics. It turns out that the world is still not ready for such major health problems. Having the health care and social services, which have been inadequate due to the high number of the infected cases (also related to the population growth in the world) and the fatal effect of the disease naturally suggests that there is a new and a questionable world order in the processes of this disease. After all the pandemics that were experienced, the functional quality of societies markedly affected, and the emergence of new changes became easier. Likewise, after COVID-19, permanent changes will emerge across the world and in many sectors including working and professional fields. In this article, after mentioning the short historical stories of the three pandemics in human history, we will remark on the COVID-19 pandemic experienced today in the discussion and conclusion section.
\end{abstract}

Structured Abstract: History is the continuation of life. Maybe it is a wide summary of the life story. Among general history branches, medical history is not just a field that examines the history of a profession. There are also trails of human history in it. The part covered by the history of medicine is very wide within the broad history information that enables the establishment of the bridge between the past and the present. In this phenomenon, the information of societies about life and death is hidden. For this reason, medical historians also need to use their own self-assessment skills when examining the past. History of medicine is divided into different sections in itself. The history of infectious diseases is only one of them. It examines many different topics such as the history of infectious diseases, epidemics and pandemics, diseases and health problems and their results, and enables them to be compared with those of today and to take different lessons. Among the big pandemics seen in history, plague, syphilis, leprosy are only three of the known ones.

* * Prof. Dr. Ege Üniversitesi Tıp Fakültesi, Tıp Tarihi ve Etik Anabilim Dalı

Prof. Dr. Ege University Faculty of Medicine, History of Medicine, Ethics Department

ORCID 0000-0001-7834-6616

cagatay.ustun@hotmail.com

Cite as/ Atıf: Üstün, Ç. (2020). Pandemi tarihinde üç hastalık ve Covid-19 pandemisinin sosyal etkisinin bu hastalıklarla değerlendirilmesi. Turkish Studies, 15(4), 1215-1226. https://dx.doi.org/10.7827/TurkishStudies.44303

Received/Geliş: 17 June/Haziran 2020

Checked by plagiarism software

Accepted/Kabul: 10 August/Ağustos 2020

Published/Yayın: 30 August/Ağustos 2020

Copyright $\odot$ MDE, Turkey

CC BY-NC 4.0 
The social, economic and demographic results of the negative impacts created by these pandemics are still the subject of research today. It took a long time to overcome these results, deterioration in relations between countries was experienced and desperation and fear had deep effects on people of that period. The inadequate medical facilities of that period and the unknown disease factors made the society accustomed to living with death. Although it was not scientific that ideas about the occurrence of the disease centred on factors such as evil spirits, sinfulness, and the curse of God, it was considered prevalent for that period. Not only the causes, but also the possibilities for treatment were limited. The skill of physicians who tried to treat an unknown factor was completely based on their own knowledge and experience. After the COVID-19 outbreak started in the city of Wuhan in Hubei province in December 2019, thanks to the warning of WHO, 'the disease turned into a pandemic', the countries' struggle to cope with the first attack began. This disease, which was effective in a short time, expanded its circle due to the speed and effect of its transmission. Currently (May 2020), the number of cases in the world is at the level of 2.995 .757 and deaths are at the level of 207.021. Today, outbreaks generally follow a steady course and do not reach a pandemic level such as COVID-19. Close individual contact and droplet particles have an important role in the rapid spread of the COVID-19 outbreak, which is still ongoing, in terms of high infectivity of the virus and transmission ways. For this reason, although the disease is seen as an epidemic in a certain region of China, it has become a pandemic by spreading all over the world as a result of international travels. Social isolation and quarantine measures taken after the disease was seen were intended for reducing the effect of this pandemic. The COVID-19 pandemic has not reached such a level as effective as the Spanish flu seen in history between 1917 and 1918. However, COVID-19 continues to cause uneasiness and anxiety due to factors such as damage caused by the disease in the body, the length of the healing process, the fatal prognosis, its rapid transmission and higher risk of mortality especially in the groups of 65 years old and older. In fact, when we look at the history of infectious diseases, we see that COVID-19 is not in a place other than the previous examples. This is because the emergence and disappearance of all the diseases occurred within a certain time. The COVID-19 pandemic still continues to be effective all over the world. Although it is pleasing that infected cases and those who have recovered as well as those who died the world has, it is uncertain how long this process and disease preventive measures for the disease will last. This pandemic affected many different areas due to the size of the COVID-19 affected area, its high contagiousness, and had impacts on the ethical and moral circles, sociocultural structure, economy, tourism and travel, agriculture, food supply chain, logistics, education, individual and social relations. The main issue mentioned today is that even if there is a decline in the course of the epidemic, nothing will be the same as before. Unfortunately, due to the fact that the history of medicine is not known or cared for, and these issues are ignored, there is a panic about what can be done because the historical past is not thought in every new and major health problem. COVID-19 is not the biggest pandemic known in human history. I think that there will be an improvement in finding the treatment or vaccine by carrying out studies on this disease, which is tried to overcome, thanks to the developing technical and knowledge. Expecting new diseases and new microorganisms should not surprise us after we damage the environment and nature and change the natural habitat. For this reason, we must adopt a harmonious and livable life and keep ourselves away from exaggeration, excessive consumption and its harm. After the COVID-19 pandemic, when the return to normal begins to take place, it is necessary to increase the sharing of ideas and suggestions of experts of philosophy, ethics, sociology, and to create a livable sharing, environmentally sensitive system by creating new committee on these issues. It should be kept in mind that with the death of people aged 65 and over, the group at higher risk from the COVID-19 pandemic, there will be a loss in the social memory of the societies they have sense of this age, and that the connection between the present and the past will therefore weaken or even break. One has to find the fact that he/she must live in a life full of not only logic, but also emotions by thinking, researching, think more consciously, without giving up her/his emotional type. Lessons we learned from the COVID-19 should not upset us, however; new ideas should be generated upon its positive effects.

Keywords: History of medicine, pandemic, disease, COVID-19, social effect, evaluation

Öz: Tıp tarihi açısından incelendiğinde dünyada yaşanmış büyük pandemilerin olduğu ve bunların tıbbi, sosyal, etik ve ahlâki sonuçlarının ortaya çıktığı bilinmektedir. Hastalık etkeni kavramının geçmiş yüzyıllarda bilinmemesi nedeniyle bundan etkilenen toplumların korku, endişe ve panik içinde kaldığı, farklı değişimlerin yaşandığı görülmektedir. Ancak özellikle son 100 yıl içinde tıbbi teşhis ve tedavi olanaklarının artması sebebiyle hastalıkların geçmiş dönemdeki kadar etkin olmadığı fark edilmektedir. Buna rağmen 20. yüzyılda HIV ve AIDS, 21. yüzyılda SARS, MERS, Ebola gibi viral hastalıkların büyük sağlık sorunları

Turkish Studies, 15(4) 
oluşturduğu inkâr edilemez gerçektir. Son olarak Çin'in Hubei eyaleti Wuhan kentinde Aralık 2019 tarihinde başlayan ve COVID-19 olarak nitelendirilen viral bir salgın hastalığın hızla dünya geneline hızla yayılarak pandemi şekline dönüşmesi, pandemilerin tarihinin gidişatını değiştiren bir duruma sebep olmuştur. Görülmüştür ki, dünya hâlâ bu tür büyük sağlık sorunlarına karşı hazır değildir. Artan dünya nüfusunun da etkisiyle, hastalığın bulaştığı kitle sayısının yüksekliği ve ölümcül etkisinin yüksekliği yüzünden yetersiz kalan sağlık bakımının ve sosyal hizmetlerin bu hastalığın süreçlerinde bazı olumsuzluklara sebep olması yeni ve sorgulanması gereken bir dünya düzeninin varlığına işaret etmesi doğaldır. Yaşamış bütün pandemilerin sonrasında toplumların işlevsel yapısı derinden etkilenmiş, yeni değişimlerin ortaya çıkması kolaylaşmıştır. Aynı şekilde COVID-19 sonrasında da dünya genelinde ve birçok sektörde, çalışma ve mesleki alanda kalıcı değişimler ortaya çıkacaktır. Makalede, pandemi tarihindeki üç hastalığın kısa tarihsel öykülerine değindikten sonra, günümüzde yaşanan COVID-19 pandemisiyle birlikte değerlendirmesini tartışma ve sonuç bölümünde yapacağız.

Anahtar Kelimeler: Tıp tarihi, pandemi, hastalık, COVID-19, sosyal etki, değerlendirme

\section{Giriş}

2019 yılının Aralık ayında Çin'in Wuhan kentinde ortaya çıkan, başlangıçta etiyolojisi belli olmayan pnömoni vakaları bildirilmiştir. Hastalıkla ilgili yapılan analizler sonucunda, etkenin yeni bir koronavirüs olduğu anlaşılmış ve 2019-nCoV (novel coronavirus ya da COVID-19) olarak adlandırılmıştır. COVID-19 salgının kısa sürede dünya geneline yayılması üzerine Dünya Sağlık Örgütü (DSÖ) tarafından 11 Mart 2020 tarihinde pandemi olarak ilan edilmiştir.

Makalenin hazırlandığı Ağustos 2020 itibariyle, Dünyada COVID-19 tanısı almış toplam olgu sayısı 21.092.096, ölüm sayısı 757.727 olarak verilmiştir (URL 1). Türkiye'de ise toplam enfekte olgu sayıs1 245.635, ölenlerin sayısı 5912 kişi olarak bildirilmiştir (URL 2).

Bulaşıcı hastalıkların salgın şeklinden kıtalara yayılan pandemiler haline dönüşmesi, insanlık tarihi kadar eski bir sorunun temelini oluşturmaktadır. Her birinin ortaya çıktığı dönemde kendi içinde farklı öyküler ve izler bırakması doğaldır. Bu tarihsel döngüyü bilmeden, yani pandemilerin tarihini anlamadan, COVID-19 pandemisinin etkilerini ve geleceğini anlamak mümkün olmayacaktır. Tıp tarihinin görev ve sorumluluk alanı gereği, geçmişte yaşanmış bazı pandemilerin kaynaklara dayanarak bugünün doğru bilgilendirilmesi ve bilinçlendirilmesi bu makalenin temel hedefini ortaya koymaktadır.

\section{Epidemi ve Pandemi Terimlerinin Tanımları}

Bulaşıcı hastalıkların izlenmesinde epidemi veya pandemi şeklinde bir ayrımın yapıldığı gözlemlenir. $\mathrm{Bu}$ ayrım, hastalı̆̆ın yayıldığı bölge genişliklerine değerlendirilir. Epidemi; bir topluluk veya bölgede görülen salgın, pandemi ise; birçok ülkede veya kıtada epidemilerin yaygın olarak görülmesi şeklinde tarif edilebilir. Tıp tarihinde epidemi terimi, Hippokrakes (M.Ö. 5.yy) tarafından genellikle güncel ve yaygın olan bir hastalığı tanımlamak için kullanılmış, epideminin belirli bir yerde veya zamanda veya yılın belirli bir mevsiminde hastalığa veya hastalık tipine karşı genel bir duyarlılık anlamına geldiği ifade edilmişti. Ona ait olduğu düşünülen Corpus Hippokratikum külliyatı içinde "Epidemikler" başlıklı eserin varlığı bu konuya verdiği önemi göstermektedir (Skinner, 1961: 310; Üstün, 2003: 25-28).

Günümüzde yaşanan salgınlar genellikle sabit bir seyir izler ve COVID-19 gibi pandemik bir seviyeye ulaşmaz. Halen devam etmekte olan COVID-19 salgınının bu kadar hızlı yayılmasında, virüsün bulaştırıcılık özelliğinin yüksek oluşu ve bulaşma yolları açısından yakın bireysel temasın ve damlacık yolunun önemli rolü olduğu bilinmektedir. Bu nedenle hastalık, Çin'in belli bir bölgesinde epidemi şeklinde başlamasına karşın, ülkelerarası yolculuklar ve etkileşimler sonucunda kısa sürede tüm dünyaya yayılarak pandemi haline dönüşmüştür. 


\section{Tıp Tarihi Açısından Hastalık Kavramı}

Tarihsel süreç incelendiğinde, birçok eski toplumda hastalıkların nedeni hakkındaki genel yaklaşım; insanların ruhların ve Tanrıların/Tanrının gazabına uğraması veya kötü ruhların tesiriyle hastalığın oluşmasına ilişkindir. Bu geleneksel yaklaşımın batıda Ortaçağın sonuna kadar devam ettiğini biliyoruz. Doğuda ise, o dönemin Rönesans'1 yaşanmaktaydı ve İbn-i Sînâ'nın da belirttiği gibi, hastalıkların ortaya çıkmasında gözle görülmeyen küçük varlıkların etkisinden bahsedilmekteydi. Batı dünyası Rönesans'a geçiş yaptıktan sonra, doğudaki bu fikirlerin desteklendiği ve hastalıkların sebepleri üzerine yoğunlaşıldığ 1 görüldü. Ancak yine de tam anlamıyla belli bir hastalık etkeni saptanması için 17 ve 18 . yüzyıldan itibaren bu canlıları gösteren merceklere dayalı mikroskop'un geliştirilmesi gerekiyordu. Talihsiz olan durum, eski batıl inanışlar ve yaklaşımlar sebebiyle, geçmiş yüzyıllarda bulaşıcı hastalıklardan ölenler, hiçbir zaman hastalıklarının nedenine ilişkin doğru bir veriye sahip olamadılar (Uzluk, 1958: 3-7; Ünver, 1938: $1-6)$.

\section{Tıp Tarihinde Yer Almış Bazı Pandemilerin Tasnifi}

Genel hatları itibariyle tarihte derin etkiler bırakmış salgın hastalıkların oluşturduğu epidemiler ve pandemiler şöyle tasniflenebilir:

- M.S. 165-180'de Antonine salgını (Bu salgının çiçek veya kızamık hastalığı olduğuna inanılmaktadır. Yaklaşık 5 milyon ölüm olgusu)

- M.S. 541-542'de Justinian vebas1 (Etken Yersinea pestis, fareler pireler üzerinden. Yaklaşık 30-50 milyon ölüm olgusu)

- 1347-1351'de bubonik veba (Black Death-Kara Ölüm) salgını (Etken Yersinea pestis, fareler pireler üzerinden. Bu salgının Avrupa nüfusunun tahmini olarak \%30 ila 50'sini yok ettiğine değinilmektedir- Dünya geneli toplam 200 milyon ölüm olgusu)

- 1520'den bugüne kadar gelen Çiçek hastalığ (Etken Variola major virüs, yaklaşık 56 milyon ölüm olgusu)

- 1629-1631 İtalyan Vebası (Etken Yersinea pestis, fareler pireler üzerinden. Yaklaşık 1 milyon ölüm olgusu)

- 1817-1923 Kolera pandemisi [Hastalık 6 atak yapmıştır] (Etken Vibrio cholerae, Yaklaşı 1 milyondan fazla ölüm olgusu)

- 1918-1919 İspanyol gribi (Etken H1N1 virüs, domuzlar üzerinden. Dünya nüfusunun 1/3'nün bu hastalığa yakalandığı ve yaklaşık 50 milyon insanın öldüğü tahmin edilmektedir) ölüm olgusu)

- 1889-1890 Rusya gribi (Etkenin H2N2 virüsü olduğuna inanılıyor. Yaklaş1k 1 milyon

- 1957-1958 Asya gribi (Etken H2N2 virüs, 1,1 milyon-bazı kaynaklarda 2 milyon ölüm olgusu)

- 1968-1970 Hong Kong gribi (Etken H3N2 virüs, yaklaşık 1 milyon ölüm olgusu)

- 1981 y1lında başlayan ve halen devam etmekte olan HIV/AIDS (Etken virüs, Şempanzeler üzerinden. 25-35 milyon ölüm olgusu)

- 2002-2003 SARS (Etken Coronavirüs, yarasalar ve misk kedisi üzerinden. 916 ölüm olgusu)

- 2009-2010 Swine Influenza Virus (Etken SIV/ H1N1 virüs, domuzlar üzerinden. 200.000 ölüm olgusu) 
- 2014-2016 Ebola (Etken Ebola virüs, vahşi hayvanlar üzerinden, 11.000 ölüm olgusu)

- 2012'den günümüze kadar gelen MERS (Etken Coronavirüs, yarasalar, develer üzerinden. 866 ölüm olgusu)

- 2019'dan günümüze kadar gelen COVID-19 (Etken Coronavirüs, yarasalar, pangolinler üzerinden. 207.021 ölüm olgusu) (URL 3; URL 4; URL 5; Qui, 2017: 3-11).

\section{Tıp Tarihinde Üç Büyük Pandemi Hakkında Kısa Bilgiler} paylaşacağız.

$\mathrm{Bu}$ bölümde bulaşıcı hastalıklar tarihindeki bazı hastalıklar hakkındaki bilgileri

\section{Veba}

Tıp tarihinde 1347 vebası olarak da bilinen hastalık, tâûn, black death/kara ölüm, bubonik veba (hıyarcıklı veba) gibi ifadelerle tanımlanmıştır. Veba, eski çağlardan beri M.Ö. 9 ve 10 yüzyıldan beri bilinen ve yüksek ölüm oranları ile seyreden bir hastalıktı. Buna bir örnek eski Yunan döneminde görülen, yaklaşık 100.000 kişinin öldüğü M.Ö. 5.yüzyıl Atina vebasıdır. Hastalığın tedavisi veya yapılması gerekenler hakkında dönemin usta hekimlerinin, özellikle Hippokrates'in bir şey söylememesi, sadece vebanın girdiği yerlerin yakılarak terk edilmesini önermesi, hastalığı gizemli bir hale getirmiştir. Hippokrates gibi İbn-i Sînâ da veba hakkında bir tedavi yöntemi önermemiş, ancak hastalığa ilişkin bazı bilgilere Kanun isimli eserinde yer vermiştir: "Yaz sonu veya sonbaharın başlangıcında yıldız kaymaları çok olur. Sabah rüzgarlar güneyden eser, hava sikıntılıdır, yeryüzünde sis vardır. Yağmur yağacağı hissedilirse de yağmaz, hava değişerek kuru bir hal alır. Böyle havalardan sonra kuş fena olur. Yaz vebası ise daha kötü olur. Veba olacă̆l yıllar kurbağalar çoğalır, böcekler artar, fare gibi toprak içerisinde yaşayan hayvanlar toprağın yüzüne çıkarak sersem sersem dolaşırlar" (URL 6; URL 7; Köker, 1984).

14. yüzyıl vebası oluşuncaya kadar Doğu'da meydana gelen birkaç veba salgını hastalığın etkisin daha iyi tarif edecektir. Elimizdeki kayıtlara göre 1015 yılında Basra'da şiddetli bir veba salgını olmuş, bu esnada mezarcıların ölüleri defnedemez hale geldikleri aktarılmaktadır. 1016 yılında Anadolu'nun da içinde olduğu coğrafyada veba salgını meydana gelmiş, büyük nüfus kaybı yaşanmıştır. Bunun devamı 1036 ve 1040 yıllarında görülen veba salgınlarıdır. 27 Şubat 1092 ve 25 Şubat 1093 tarihlerinde Anadolu'da bir başka büyük veba salgını olmuş, öyle ki papazlar ölüleri gömmeye dahi vakit bulamamışlardır. Bunların ardından 1152 yılında yine Anadolu'da, 1153-1154 yalları arasında Konya ve Kilikya'da, 1178-1179 yılları arasında Suriye, el-Cezire, Irak, Musul, elCibal bölgelerini etkileyen veba salgınları nüfus kayıplarına ve kıtlık yaşanmasına sebep olmuştur. $\mathrm{Bu}$ salgınların 13. yüzyıl boyunca bölgede etkisini devam ettirdiği görülmektedir (Güçlüay, 2000:35-52).

Avrupa'da görülen 1347 vebası, kara ve deniz ticaret yolları boyunca kısa sürede yayılmış, kitle ölümlerinin olması sebebiyle toplumlarda büyük korkuya neden olmuştur. Bu dönemdeki durumu en iyi tanımlayan, 1347-1351 yılları arasında etkin veba salgınında Floransa'daki gündelik yaşamını anlatan ve halk ağzıyla yazılmış, toplam 100 öyküden oluşan Giovanni Boccaccio'nun (1313-1375) Decameron isimli eseridir. Eser, bu salgına tanık olmuş yazarın gözlemlerini içerdiğinden, hastalığın boyutlarının anlaşılması için kaynak niteliğinde sayılabilir. ......Italya'nın ünlü kentlerinden en soylusu Floransa'da ölüm saçan bir veba salginı baş gösterdi. İster yıldızların etkesiyle ortaya çıkmış olsun, ister insanların işledikleri suçlar nedeniyle Tanrı tarafindan gönderilmiş olsun, veba birkaç yıl önce doğu ülkelerinde görülmüss, çok sayıda can kaybına yol açmıştı. Daha sonra durmadan yayılarak Batı'ya ulaştı. Koruyucu önlemler etkisiz kaldl..., Bir cenaze gömeceklerini sanan papazlar, altr, sekiz, kimi kez de daha fazla cenaze gömmek zorunda kalıyorlardı. Üstelik ölüler gözyașı, mum, cenaze alayı gibi saygl gösterilerinden de yoksun birakllyyordu. Tersine ölüm öyle sıradan bir olay olmuştu ki, ölenlere bugün keçi 
leşlerine gösterilen saygı bile gösterilmiyordu..... .....Kim bilir ne ünlü aileler, ne büyük topraklar, ne değerli servetler yasal mirasçısız kalmuştı (Boccaccio, 1996:21-27).

Dönemin tarihçilerinin aktardığına göre, vebadan ölenlerin sayısı o kadar çoktu ki, ölülerin gömülmesine yer olmadığı için cesetler açıkta istiflenmiş veya denize atılmıştı. Şehirlerdeki ağır ölü kokusu dayanılır gibi değildi.

1347 vebası Hindistan ve Güneybatı Rusya'dan batıya doğru hızla yayıldı. Kırım'ın güneydoğusundaki Caffa şehri Tatarlarca kuşatılmasına rağmen, hastalığa yakalanan Tatar ordusunun toplu halde ölmesi sayesinde kurtulmuşlardı. Ancak asıl felakete neden olan, geri çekilen Tatarların vebadan ölen askerlerin cesetlerini sapanlarla şehre atmalarıydı. Bulaşıcılık ve bulaştırma kavramlarının o dönemlerde anlaşılmış olduğunu gösteren bu yaklaşıma rağmen, salgından korunma yolları bilinmiyordu. Gröndland'a kadar bütün Avrupa'yı saran veba sebebiyle bir yıl içerisinde Avrupa nüfusunun dörtte biri kaybedildi. Hastaların \%70'i 5 gün içinde ölüyordu. $\mathrm{O}$ dönemde hastalığın Tanrı'nın bir laneti olduğunun kabulünün yanında, astroloji ile ilişkilendirilmesine de çalışıldı. 1345'de Jüpiter, Satürn ve Mars'ın uyumsuz dizilişinin bu salgına neden olduğu ileri sürüldü. Bu uygun olmayan diziliş sebebiyle Belçikalı astronom Simon de Covino hastalık için Black Death (Kara Ölüm) (1350) terimini kullandı. Hastalığın yayılmasında hekimlerin öngörüsü Miasma teorisi üzerinde yoğunlaşıyordu. Veba'nın bu hızlı ilerleyişi acizlik, yalnızlık ve korkuyu beraberinde getirdi. Hastalığı tedavi etmeye çalışan hekimler mümkün olduğunca kendilerini çürüyen cesetlerin ve boşalan hıyarcıkların kötü kokusundan koruyan, içinde sirke ve hoş kokuların bulunduğu uzun gagalı maskelerden, uzun pelerinli mumlu elbiselerden, hastalara dokunmadan bakmak için bir değnekten yararlandılar. Oluşan bu karamsar atmosfer toplumlarda yaygin bir tedirginliğe neden oldu (Lyons, 1987; Mussap, 2019).

Hastalığın Kara Ölüm şeklinde nitelendirilmesinin bir başka sebebi, hastalarda solunum yetmezliği, dissemine intravasküler koagülasyon (DIC) sonucunda hastanın vücudunda belli bölgelerde deri renginin koyu mor, siyah bir hal alması ve ölümün bu kötü genel görüntüyle gerçekleşmiş olmasındandır

1347 vebasının başlamasıyla hastalığın önlenmesine ve etkisinin azaltılmasına yönelik bazı yeni fikirler ortaya çıktı. Bunlardan birisi karantinadır. Karantina terimi, 14. yüzyıl vebası sırasında Adriyatik'te Venedik'in karşısında bulunan Ragusa'da limanlara yanaşacak gemilerin bulaşıcı hastalığı getirme endişesini önlemek için açıkta önceki yaklaşıma göre 30, sonra ki yaklaşıma göre ise 40 gün boyunca bekletilmesi prensibinden ortaya çıktı. Kelimenin kökeni İtalyanca 40 gün anlamına gelen "quaranta giorni" "ye dayanmaktadır (URL 8).

14. yüzyıl vebasının Avrupa'daki etkisi farklı dönemlerdeki ataklarla 17. yüzyılın sonuna kadar devam etti. Bu pandeminin siyasi ve ekonomik çalkantılara eşlik eden farklı sonuçları oldu. Kitlesel ölümler sebebiyle kısa süre içinde yoğun nüfus kaybı yaşanarak, aileler, çocuklar, akrabalıklar ve arkadaşlıklar gibi kavramlar zedelendi. Kent nüfuslarındaki azalmalar köy ile kent arasındaki ekonomik ilişkileri durma noktasına getirdi. Ekonomik yetersizlikler sebebiyle aç ve çaresiz kalan köylülerin kentlere göç etmesiyle araziler bakımsız ve başıboş kalmış, göç etmeyip orada kalanlar bunların sahibi oldu. Bu büyük el değiştirmenin sonucunda bu bölgelerde refah seviyesini artıran gelişmeler yaşandı (Garrison, 1929:188).

Gerçek şudur ki, vebanın hızlı yayılmasında, o dönemin kötü hijyen koşullarının, aşırı kalabalık nüfusun, savaşların ve iklim değişimlerinin yaygın bir etkisi de olmuştur denilebilir.

\section{Cüzzam (Lepra)}

Arapça'da "elin kesilmesi, parmakların düşmesi” anlamına gelen cezem kökünden türetilen cüzâm kelimesi, özellikle bulaşıcı lepra (lepromatous leprosy) olgularında ortaya çıkan ciddi şekil bozukluklarını ifade eder ve Türkçe'de daha çok cüzzam şeklinde söylenir (URL 9). 
Kara ölüm-veba'nın ardından ortaya çıkan cüzzam (lepra), batı toplumlarında büyük korku ve paniğe neden olmuş bir hastalıktı. Aslında cüzzamın yeryüzündeki varlığı daha eskilere gitmekteydi. Cüzzam'ın MÖ 300'de Büyük İskender'in askeri birlikleri tarafından Hindistan'dan Avrupa'ya geldiği ileri sürülmektedir. Ortaçağ'da Avrupa ve Orta Doğu'da görülme sıklığı yüksekti. Sosyoekonomik gelişme nedeniyle olgu sayısı 1870 yılı ve civarında önemli ölçüde azalmıştır (Lastória,2014).

Eski Mısır, Çin ve Hindistan uygarlıklarında bilinen cüzzam, kıta Avrupa'sında Ortaçağ süresince düşük seviyede görülürken, Haçlı Seferlerinden dönen askerlerin gelmesiyle olgu sayısı artmaya başladı. O zamana kadar bulaşıcı olmayan veya çok az bulaşıcı olan birçok cilt hastalığı da cüzzam olarak nitelendirilmekteydi. Ancak cüzzamlı olan kişilerin varlığı toplumları her zaman tedirgin etti. Bu hastalığa maruz kalanların Tanrı'nın gazabına uğradığı ya da lanetlendiği, ahlâken düşük seviyede kişiler olduğuna inanılırdı. Aslında cüzzam bir yoksul hastalı̆̆g gibi algılansa da zenginler arasında da görüldüğü olurdu. Babil döneminde olduğu gibi hastaların farklı ve belirleyici giysiler giymesinin yanı sıra toplumun bir arada olduğu yerlerde, dua ayinlerinde bile ayrılmaları ve izole edilmeleri zorunluydu. Enfekte olanlar fiziksel ve törensel olarak kirli olarak kabul edildiğinden, bu hastalık korkunç ve kirletici olarak kabul edildi. İbranice İncil'de cüzzam genellikle Tanrı'nın günahkâr davranışlar için cezası olarak görülüyordu. Cüzamlıların ölü olarak yaşadıklarına inanılır ve ölümle eş değer anlamda ilişkilendirilirdi. Hıristiyanlıkta, ilahi hekim olarak da kabul edilen Hz. İsa'nın cüzzamlı hastayı iyileştirme mucizesi, hastalığın dini ve mistik bir anlam kazanmasına sebep oldu (Lewis, 1998:63; Viljoen, 2014:1-7; Mc Tavish, 2018:18-23).

Cüzzam hastalarının vücutlarındaki lezyonlar sebebi ile toplumda korku ve tedirginlik uyandırması yüzünden toplu yaşam alanlarında bulunmaları mümkün değildi. Bunlar bir yerleşim yerinden geçerken elinde taşıdığı küçük çanı çalarak çevredekilere geçtiğini haber verirdi. Sokaktaki insanlar bunu fark ettiğinde evlerine kapanırlar, sokak boşalırdı (Cochrane, 1996:79).

Hz. Muhammed'in de cüzzam hastalığına önem verdiği ona atfedilen sözlerinden anlamak mümkündür. Bunlar bazıları şunlardır: Cüzzamlıdan arslandan kaçar gibi kaçınız. O bir vadiye inerse siz başka vadiye ininiz., Cüzzamlı hasta ile aranızda bir mızrak boyu mesafe olduğu halde konuş. Yine bir gün bir cüzzamlı Hz. Muhammed'in yanına gelir. Bunu görünce Peygamberimiz yanındaki kişiye; Yaygıyı topla, üzerine ayakları ile basmasın dediği rivayet olunur. Görüldüğü gibi cüzzam İslamiyet'ten önce olduğu gibi sonrasında da büyük önem arz eden bir hastalıktı (Süheyl, 1934).

Selçuklular ve Osmanlılar döneminde, cüzzamlı hastaların şehir dışında, halka temasını önleyen yerlerde yapılmış ve halkın merhametini sağamaya yönelik miskinhanelerde (miskinler dergâhı, miskinler tekkesi) ikamet etmeleri sağlanırdı. Bu sosyal izolasyonla toplumdan soyutlanmış cüzzam hastaları bir arada yaşarlardı. Evliya Çelebi de Seyahatnamesinde bu durumu dikkati çekmiştir. Anadolu Beylikleri döneminde Zülkadiroğulları Kayseri'de bir cüzzamhane inşa etmişlerdir. Bu yapının yapılış yılı bilinmemekle birlikte 15. yüzyıldan 18. yüzyıla kadar işlevini devam ettirmiştir. Osmanlılar döneminde ise Edirne, İstanbul, Bursa, Kıbrıs ve Girit’te cüzzamhane yapılmıştır (Ünver, 1961).

Hasta sayısının çokluğu ve hastaların sosyal yaşamdan soyutlanması, dışlanma yüzünden işsiz ve aç kalması neticesinde 11 ile 14. yüzyıllar arasında İngiltere'de cüzamlıların bakımı için kasabaların ve şehirlerin kenarında ya da kırsal alanlarda, kavşakların ya da önemli seyahat yollarının yakınında 320 kadar cüzamlı veya 'lazar' evleri inşa edildi (URL 10).

Cüzzam'1n etkeni Mycobacterium leprae isimli bakteridir.

\section{Sifiliz (Frengi)}

$\mathrm{Bu}$ hastalık tanındığı zamandan beri, klinik önemi sürdürmeye devam etmektedir. Her hastalığ 1 taklit eden, y1llarca gizli kalabilen, birey, aile, toplumsal ve sosyal yaşamı etkileyen ve 
cinsel yolla bulaşan sifiliz'in en tehlikeli yönü, anneden bebeğe geçebilen ve nesilleri etkileyen bir sağlık sorunu olmasıdır. Bu konjenital geçiş, salgının yaygın olduğu Avrupa'da birçok kişinin bundan etkilenmesini ve hastalığa yakalanmasını sağladı. Bu yüzden geçmiş döneme ait, özellikle portre tablolara konu olan kişilerin doğuştan bu hastalığı taşımaları sebebiyle yüz görünümlerinde hastalığa ilişkin lezyonların da resmedilmiş olması dikkat çekicidir. Sifiliz, özellikle 15. yüzyılın sonlarından itibaren etki göstermiş, 16. yüzyılda da varlığını devam ettirmiş, cinsiyet, milliyet tanımayan, çocuk, genç, ileri yaş ayrımı yapmayan bir hastalıktı (Behçet, 1936:3-5).

Sifiliz, Ortaçağ’ın sona erdiği sırada, 1494 yılında Avrupa'nın yeni tanıştı̆̆ı bir hastalıktır. Hastalı̆̆ın Avrupa'da Fransa kralı VIII. Charles'ın ordusunun İtalya'ya girmesi (1494) ve Napoli'yi kuşatan askerler arasında görülmesiyle ortaya çıtı̆̆ belirtilir (1495). Bu nedenle hastalığa Fransız veya Napoli hastalığı denilmesi de söz konusudur. Kimi araştırmacılar hastalığın Christopher Columbus'un Amerika'ya seyahati ile Avrupa'ya geldiğini ileri sürerlerse de, bunun doğruluğu tartışmalıdır (Aydın, 2006:103; URL 11).

İtalya seferindeki savaş koşulları ilk sifiliz salgını için elverişli bir ortama sahipti. Hem Fransız hem de İtalyan orduları, tüm Avrupa'dan getirilen paralı askerlerden oluşuyordu ve paralı askerler ile yerel kadınlar arasındaki evliliklerin yanında, tecavüz ve fuhuşun yaygınlaşmasıyla hastalık yayıldı. Paralı askerlerin anavatanlarına dönmelerinin ardından salgın hızla Avrupa çapında bir boyut kazandı (Tampa, 2014:4-10).

Ancak bu hastalığın eski zamanlardan beri yeryüzünde varlığı söz konusudur. O dönemlere ait mezarlardan çıkan iskeletlerdeki lezyon kalıntıları ve izleri bunu ispatlar niteliktedir. Geçmiş yüzyıllarda Sifiliz'e benzer hastalıkların tarifi yapılmıştı. Buna örnek olarak, Hippokrates'in kasıklarda şişlik ve ağızda aft ve yara oluşturan bir hastalıktan bahsetmesi, Celsus'un cinsel organda sert ve yumuşak olmak üzere iki tip ülserin bulunduğu bir hastalı̆̆ açıklaması verilebilir. Hastalı̆̆ın sifiliz ismiyle bilinmesi, şair ve hekim Girolamo Fracastoro (Fracastorius) (1478-1553) sayesindedir. Frocastoro, Syphilis sive morbus gallicus isimli manzum eserinde (1530) efsanevi çoban Syphilus'un Yunan Tanrısı Apollon'u kızdırdığını, öç almak isteyen Tanrının da, kol ve bacaklarından etlerinin düşmesine neden olan, kemiklerinin gözükmesini sağlayan, dişlerini çürüten, nefesinin kokutan, sesini bozan, syphilis adında bir laneti ona musallat ettiğini anlatır. Fracastorius tarafından hastalığın isminin bu çobandan köken aldığı ileri sürülmüştür. Hastalığa zührevî anlamında vénérien (Mal vénérien) adının verilmesi, 1527 y1lında hekim Jacques de Béthencourt (16.yy) tarafından yapıldığı belirtilmektedir. Hastalığın çeşitli isimleri 18. yüzyılın sonuna doğru tıp biliminde sililiz terimi kabul edilinceye kadar kullanıldı. Nihayet 1777 yılında hekim William Cullen'in (1710-1790) kitabında sifiliz (sypilis) terimini kullanmasından sonra bu isim tüm dünyada kabul edildi. Sifiliz'in Doğu dünyasında farklı isimlerle bilindiğini biliyoruz. İranlılar âbile-i frenk, zahm-i frenk, rîş-i frenk şeklinde kullanarak Fransızlara mal ettikleri gibi, Ermeni-dâne adını dahi kullanmışlardır. Araplar da Fransızlara mal ederek hubbü'l Frensiye demişlerdir. Bizde ise frengi veya efrenç isimlerinin yanında, Vebâü'l-Efrencî, maraz-1 İspanya, maraz-1 Hindî, dâü'l-Efrenç kelimeleriyle de bilinmektedir. Frengi kelimesi ile hastalığın Fransa'dan (Avrupa'dan) geldiği anlatılmaktadır (Fracastor,1933:5-26; Echeverría, 2010; Uludağ, 2010; Richter, 1956:71; İnceday1, 1949:4).

Vücut üzerinde farklı bölgelerde oluşan şankr ve gom yaraları sebebiyle ortaya çıkan kötü görünüm ve doğum yoluyla sifiliz'in bebeğe geçmesi durumu (Unat, 1945) hastalı̆̆ın Tanrı'nın lanetlediği bir özel durum olduğu inanışını güçlendirmiştir. Bu nedenle sifiliz hastaları yüzyıllarca sosyal soyutlanmaya maruz kalmışlar ve dışlanmışlardır.

Sifiliz'in etkeni Treponema pallidum isminde bir spiroket bakterisidir. 


\section{Tartışma ve Sonuç}

$\mathrm{Bu}$ makalede enfeksiyon hastalıkları tarihinde yer alan üç büyük pandemiye ait bilgileri paylaşırken, Aralık 2019'da Çin'in Wuhan kentinde ortaya çıkan, seyahat yolları ve etken virüsün bulaşıc1 etki gücünün fazla olması sebebiyle kısa sürede pandemiye dönüşen ve yeni bir hastalık olan COVID-19'un basın ve medya organları üzerinde yer almış temel sosyal etkilerine ilişkin bazı tespitlerde bulunacağız. Tarihteki pandemilerden veba, sifiliz, cüzzam (lepra) bakteri kökenli olmasına karşın, COVID-19'un viral kökenli olması etkenlerin karşılaştırılması açısından değil, hastalıkların pandemiye dönüşmüş olmasından değerlendirilmelidir. Her bakteri veya viral kökenli hastalık pandemiye sebep olmaz. Ancak yayılıma uygun koşullar ve tedavideki kısıtlllıklar, etkenin bulaş gücünün yüksek olması gibi durumlar sebebiyle hastalığın kıtalararası bir yayılıma sebep olması kaçınılmazdır. Tarihte yaşanmış üç pandemideki toplam ölüm oranının yüksekliğinin sebebi, görüldüğü çağlarda hastalıkların etkeninin bilinmemesi ve belli bir tedavi protokolünün henüz bulunamamış olmasıdır. Halen yaşanmakta olan COVID-19 pandemisinde ise etken bilinmesine karşın, halen etkin bir aşı ve tedavisi yoktur. Bu sebeple genel hastalık oluşumu ve pandemiye dönüşme anlamındaki benzerlikler, geçmişle bugün arasındaki ilişkiyi ortaya koymaktadır. Tıbbi boyutun ötesinde her hastalığın ve pandeminin sosyal bir etki alanı da vardır. Makalede incelediğimiz tarihsel kimliği olan pandemiler ile COVID-19 pandemisinin de benzer sosyal etkilere sebep olduğunu kısaca irdelemek gerekmektedir. Buradaki bilgiler tarihsel kaynaklarla ve günümüzün medya olanakları ile kamuoyuna yansıyan haberler üzerinden değerdirilecektir.

- Geçmişte yaşanmış pandemilerden veba, sifiliz, cüzzam sosyal ayrımcılığa ve bireysel izolasyona bağlı dışlanmayı gerektiren durumlar oluşturmuştur. Kitlesel ölümlerin en fazla görüldüğ̈̈ veba nedeniyle toplumun sosyal örgüsünde geniş bozulmalar ve yalnızlaşmalar yaşanmış, o dönem için mal-mülk ve para kendi içinde kısa sürede el değiştirmiş, köylerin hastalık sebebiyle boşalması, halkın şehirlere doğru göç etmek istemesi nedeniyle büyük bir sosyal hareketlilik meydana gelmiş, sifiliz ve cüzzam hastalıklarında hastaların vücutlarında görülen lezyonlar yüzünden bireysel izolasyonu ve dişlanmayı tetikleyen unsurlar oluşmuştur. COVID-19 pandemisinde özellikle kronik hastalığı olan 65 yaş ve üzeri gruplarda ölümcül seyretmesi sebebiyle bu grupların toplum içinde izolasyona maruz kalmasına sebep olmuş, karantina tedbirleri açısından bu yaş gruplarının sokağa çıkmalarına izin verilmemesi yüzünden sosyal bir yalnızlık duygusu ortaya çıkmıştır. Özellikle Avrupada bu grupların kaldığı ve bakıldığı bakım evlerinde personelin endişe ve korku yüzünden kurumu terk etmesiyle yaşlıların COVID-19'dan vefat etmesi nedeniyle etik ve ahlâki açıdan kabul edilemez görüntüler ortaya çıkmıştır.

- Veba, sifiliz, cüzzam görüldüğü çağlarda her yaş grubunda kitlesel ölümlere sebebiyet vermiştir. $\mathrm{Bu}$ yoğun nüfus kaybı özellikle belli mesleklerin yok olmasına ve yeri kısa sürede doldurulamaz boşluklara yol açmıştır. Aynı durum COVID-19 pandemisinde özellikle 65 yaş ve üzeri grupların kaybı sebebiyle toplumların yaşayan an ve toplumsal belleğinde tecrübe ve yaşanmışlık açısından kesintiler meydana getirmiştir. $\mathrm{Bu}$ yaş gruplarında olan sanatkâr, akademisyen, hekim, öğretmen gibi özellik arz eden kişilerin kaybı kültürel ve entelektüel anlamdaki eksikliği pekiştirmiştir.

- Veba, sifiliz ve cüzzam görüldükleri çağda kitlesel ölümlere neden olurken, hastalık etkeninin bilinmemesi yüzünden gizemli yönleri olduğu düşünülmüş, yaşanan endişe ve korkunun da eklenmesiyle cenazelerin ortada bırakılması veya toplu olarak gömülmesi gibi durumlar ortaya çıkmışır. COVID-19 pandemisinde milyonlarla ifade edilecek yüksek ölüm oranları görülmemesine karşın, hastalığa yönelik spesifik ve etkili bir tedavi yönteminin ya da aşının bulunmamış olması yüzünden, cenazelerin toplu halde gömülmesi gündeme gelmiş, ailelerin yakınlarına veda edemeden, yas tutamadan cenazelerini gömmek zorunda kalması ruhsal bir travmaya yol açmıştır. Ayrıca sosyoekonomik durumu bozuk bazı ülkelerde yaşanan ölüm oranı yüksekliği sebebiyle cenazelerin sokakta veya ölen kişinin yakınlarının evlerinin önüne bırakılması 
diğer üç pandemideki gibi benzer sonuçlar oluşturmuştur. Toplumsal açıdan bir tür sosyal travma kabul edilecek bu görüntülerin olumsuz etkilerinin zamanla ortadan kalkması düşünülebilir.

- Veba, sifiliz ve cüzzamın görülmeye başlandığı dönemlerden sonra, toplumların sosyal düşünce ve duygu dünyası etkilenmiş, bu etkilenme ölümün getirdiği karamsarlık üzerinden gerçekleşmiştir. Hastalıkların nedeninin henüz bilinmediği yüzyıllarda yaşanan bu durum doğal kabul edilebilir. Batının Ortaçağ sonrasına rastlayan dönemde başlayan bu hastalıkların Rönesans sonrası dönemin düşünce dünyası üzerinde olumsuz etkileri görülmüştür. COVID-19 hastalığ1 sürecinde de belirgin bir tedavi ve aşı olmaması yüzünden toplumlardaki tedirginlik ve endişe artmış, karantina tedbirleri ve sokağa çıkma yasaklarının uzun sürmesi özellikle 65 yaş üstü ve 20 yaş altı grupları aktif sosyal yaşamdan uzaklaştırarak emosyonel yönden karamsarlık meydana getirmiş̧tir. COVID-19 pandemisinin tıbbi ve sosyal etkisinin uzun süreceği düşünülebilir.

- Veba, sifiliz ve cüzzamda ölüm sayısının yüksekliğiyle paralel olarak köy nüfusunun azalması, tarım ve tarım ürünlerini yetiştirmeyi kesintiye uğratmış, o yüzyılların gıda tedarik zincirini bozmuş, şehirlerde açlık ve kıtlığın artmasına sebep olmuştur. Benzer şekilde COVID-19 pandemisinde ilkbahara denk gelen bu hastalık sürecinde tarım ürünlerinin ekim ve hasat işlemlerinin yapılmasında zorluklar yaşanmış, gıda tedarik zinciri ve lojistik hizmetler olumsuz etkilenmiştir. Günümüzün teknolojik olanaklarının gelişmişliği de göz önüne alındığında bir hastalığın böylesi yaygın olumsuz etkiler bırakması COVID-19 pandemisinin etki gücünün yüksekliğini göstermektedir. $\mathrm{Bu}$ tür durumların sosyal karışıklıklar ve hareketlenmeler yaşanmaması için ülkeler aldıkları önlemleri zamanla esnetmeye çalışmışlardır.

- Özellikle Sanayi Devriminden sonra gelişen endüstri ve teknoloji olanakları doğal çevreye ve canlılara verilen zararların artmasına sebep olmuştur. COVID-19 salgınıyla kitlesel sokağa çıkma yasakları, seyahat kısıtlamaları sayesinde doğanın kendisini kısmen de olsa yenileme sürecine girdiği, trafiğe çıkmayan araçlar, uçmayan uçaklar nedeniyle hava kirliliğinde azalma olduğu resmi otoriterlerce açıklanmaktadır. Bu olumlu etkinin biyoetik açısından kayda değer bir yararı olmasına karşın, salgından sonra tekrar eski koşullara dönülecek olması bu yararı kalıcı yapmayacaktır. Burada umutlu olmayı devam ettirmek, fosil yakıtlı araçların kısa bir zamanda elektrikli, hibrit ve diğer çevreye duyarlı olanlarla dönüşümünün sağlanması, kıtalararası ve yerel uçak seferlerinin azaltılarak gökyüzüne verilen atık gaz oranının düşürülmesi hedeflenebilir. $\mathrm{Bu}$ konularda uzman akademisyenlerin bilimsel görüşlerini ülke yönetimleri ve toplumla paylaşmasının süreci olumlu etkileyeceği düşünülebilir.

- COVID-19 salgınından sonra, normalleşmenin başladığı dönemde, yeni bir sayfanın açıldığı unutulmadan, felsefe, etik, sosyoloji uzmanlarının fikir paylaşımlarını artırması, ülkelerin bu konulara ilişkin yeni kurullar oluşturarak, yaşanabilir, paylaşımcı, çevreye duyarlı bir sistemi devreye alması gerekmektedir. Bu konuda zamanla yapılacak nitel ve nicel farklı çalışmalarla toplumların COVID-19'dan etkilenim durumlarının daha özgün bir şekilde incelenmesi mümkün olabilir.

Tarihte yaşanmış, ölüm oranları ve yayılım etki alanı genişliği açısından iyi bilinen veba, sifiliz ve cüzzam o çağların yaygın inanış biçimi sebebiyle Tanrı'nın toplumlara göndermiş olduğu bir cezası gibi algılanmıştır. Aynı şekilde olmasa da, COVID-19 pandemisi hızla yozlaşan sosyal yaşam, yitirilen etik ve ahlâki değerler açısından, farklı kültürler için bir tür kendine çeki düzen verme zamanı olarak kabul edilebilir. Çıkarılacak doğru derslerin ülkelerin anlayış farklarını en aza indirgemesi beklenmelidir. İnsan, nasıl insan olacağını düşünerek, araştırarak, vicdanından da destek alarak, sadece mantıkla değil, aynı zamanda duygularla yüklü bir yaşamın içinde var olması gerçeğini artık bulmak zorundadır. Bu yüzyılın COVID-19 pandemisi bunu anlamak için bir firsat oluşturmuştur. Bu firsatın doğru adımlarla desteklenmesi için eski ile yeni dünya düzeni arasındaki farklar saptanmalı, etik ve ahlâki düzlemi destekleyen sistemlerin oluşması ve gelişmesi çaba gösterilmelidir. 


\section{Kaynakça}

Aydın, E. (2006). Dünya ve Türk Tıp Tarihi. Güneş Kitabevi.

Behçet, H. (1936). Frengi Dersleri. Akşam Matbaası.

Boccaccio, G. (1996). Decameron. (Çev. R. Teksoy). Oğlak Yayıncılık. İkinci Baskı.

Cochrane, J. (1996). An Illustrated History of Medicine, Tiger Books International London.

Echeverría, VI. (2010). Girolamo Fracastoro and the invention of syphilis, Hist. cienc. saudeManguinhos. 17(4). 877-884.

Fracastor, J. La. Syphilis. (1963). (Çev. F.N. Uzluk). Ankara Üniversitesi Tıp Fakültesi Yayınları Sayı:197. 5-26.

Garrison, HF. (1929). An Introduction to the History of Medicine. Fourth Edition, W.B. Saunders Company.

Güçlüay, S. (2000). Tarihte Ticareti Etkileyen Unsurlar. Türk Dünyası Araştırmaları. Sayı: 126, 35-52.

İncedayı, CK. Pektaş, C. (1949). Modern Sifilologi (Teşhis-Tedavi). İstanbul Üniversitesi Yayınları No.376, s: 4.

Lastória, JC. (2014). Morgado de Abreu, MAM. Leprosy: review of the epidemiological, clinical, and etiopathogenic aspects - Part 1, An Bras Dermatol. 89(2): 205-218.

Lewis, P. (1998). Tip Tarihi. (Çev. N. Güdücü), Khalkedon Yayınları.

Lyons, AS. Petrucelli, R.J. (1987). Medicine-An Illustrated History, Abradale Press, Harry N. Abrams, Inc., Publishers. s: 345,349.

Köker, AH. (1984). İbn-i Sina ve Halk Sağlı̆̆g, İbn-i Sina Kongre Kitab1.

Mc Tavish, J. (2018). Jesus the Divine Physician. The Linacre Quarterly. Vol. 85(1), Feb.18-23.

Mussap, CJ. (2019). The Plague Doctor of Venice. Internal Medicine Journal. 49: 671-676.

Richter, R. (1956). Deri Hastalıkları ve Veneroloji. (Çev. A.L.Tat). Ankara Üniversitesi Tıp Fakültesi Yayınları No:50.Yeni Desen Matbaası.

Skinner, HA. (1961). The Origin of Medical Terms. The Williams \& Wilkins Company.

Süheyl, A. (1934). Türkiyede Cüzzam Hastalı̆̆ Tarihine Ait, Istanbul Üniversitesi Tıp Fakültesi Tıp Tarihi Enstitüsü 1934-1935 Ders Yılı Çalışması Hülasası. Belediye Matbaası.

Tampa, M. ve ark. (2014). Brief History of Syphilis. J Med Life. 15; 7(1): 4-10.

Uludăg, OŞ. (2010). Osmanlılar Devrinde Türk Hekimliği. (Hazırlayan: E. Kahya), Türk Tarih Kurumu Basimevi.

Unat, EK. (1945). Bulaşıcı Hastalıklar ve Salgınlarla Savaş, T.C. Sağlık ve Sosyal Yardım Bakanlığ Yayınlarından No. 113, İsmail Akgün Matbaası. s: 308-331.

Uzluk, FN. (1958). Genel Tıp Tarihi-I, Ankara Üniversitesi Tıp Fakültesi Yayınlarından Sayı:68. Güzel İstanbul Matbaas1.

Ünver, AS. (1938). Tıb Tarihi-I. İstanbul Üniversitesi Yaylnlarından Sayl:64. Matbaai Ebüzziya. s:1-6.

Ünver, AS. Şehsuvaroğlu BN. (1961). Türkiyede Cüzzam Tarihi Üzerine Araştırmalar. İsmail Akgün Matbaası, 3-5. 
Üstün, Ç. (2003). Tip Sanatının Ustası Hippokrates. Ege Üniversitesi Tıp Fakültesi Yayınları No. 156.

Viljoen, FP. (2014). Jesus healing the leper and the Purity Law in the Gospel of Matthew. In die Skriflig/ In Luce Verbi 48(2):1-7.

Qiu, W. ve ark. (2017). The Pandemic and its Impacts, Health. Culture and Society.Vol.910.206:3-11.

URL 1: https://www.worldometers.info/coronavirus/ (E.T: 27.04.2020)

URL 2: https://covid19.saglik.gov.tr/ (E.T: 27.04.2020)

URL 3: https://www.weforum.org/agenda/2020/03/a-visual-history-of-pandemics

URL

https://apps.who.int/iris/bitstream/handle/10665/70863/WHO_CDS_CSR_GAR_2003.11_eng.pdf? sequence $=1 \&$ isAllowed=y $($ E.T: 23.04 .2020$)$

URL 5: http://www.emro.who.int/pandemic-epidemic-diseases/mers-cov/mers-situation-updatejanuary-2020.html (E.T: 23.04.2020)

URL 6: https://www.sciencedirect.com/science/article/pii/S0096300319307684 (E.T:23.04.2020)

URL 7: https://islamansiklopedisi.org.tr/taun (E.T: 22.04.2020)

URL 8: https://www.etymonline.com/word/quarantine (E.T: 22.04.2020)

URL 9: https://islamansiklopedisi.org.tr/cuzzam (E.T: 24.04.2020)

URL 10: https://historicengland.org.uk/research/inclusive-heritage/disability-history/10501485/time-of-leprosy/ (E.T: 24.04.2020)

URL11: https://www.britannica.com/topic/Syphilus (E.T: 24.04.2020) 